5-1992

\title{
Rape and Dimensions of Gender Socioeconomic Inequality in U.S. Metropolitan Areas
}

\author{
Ruth Peterson \\ The Ohio State University, peterson.5@sociology.osu.edu \\ William C. Bailey \\ Cleveland State University, w.bailey@csuohio.edu
}

Follow this and additional works at: https://engagedscholarship.csuohio.edu/clsoc_crim_facpub

Part of the Criminology Commons, and the Inequality and Stratification Commons

How does access to this work benefit you? Let us know!

\section{Original Citation}

Peterson, R. D., , \& Bailey, W. C. (1992). Rape and Dimensions of Gender Socioeconomic Inequality in U.S. Metropolitan Areas. Journal Of Research in Crime and Delinquency, 29(2), 162-177. doi:10.1177/

0022427892029002004

\section{Repository Citation}

Peterson, Ruth and Bailey, William C., "Rape and Dimensions of Gender Socioeconomic Inequality in U.S. Metropolitan Areas" (1992). Sociology \& Criminology Faculty Publications. 85.

https://engagedscholarship.csuohio.edu/clsoc_crim_facpub/85

This Article is brought to you for free and open access by the Sociology \& Criminology Department at EngagedScholarship@CSU. It has been accepted for inclusion in Sociology \& Criminology Faculty Publications by an authorized administrator of EngagedScholarship@CSU. For more information, please contact library.es@csuohio.edu. 


\title{
RAPE AND DIMENSIONS OF GENDER SOCIOECONOMIC INEQUALITY IN U.S METROPOLITAN AREAS
}

\author{
Ruth D. Peterson, Ohio State University \\ William C. Bailey, Cleveland State University
}

This article was originally published in:

Peterson, Ruth D. and William C. Bailey (1992). Rape and Dimensions of Gender Socioeconomic Inequality in U.S Metropolitan Areas. Journal of Research in Crime and Delinquency, 29(2), 162-177.

Post-print standardized by MSL Academic Endeavors, the imprint of the Michael Schwartz Library at Cleveland State University, 2013

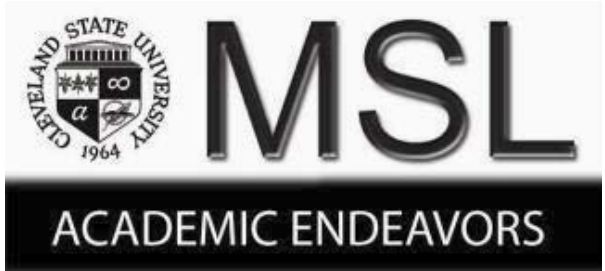




\title{
RAPE AND DIMENSIONS OF GENDER SOCIOECONOMIC INEQUALITY IN U.S. METROPOLITAN AREAS
}

\author{
RUTH D. PETERSON \\ WILLIAM C. BAILEY
}

There is a growing consensus that a major cause of the rape problem is the subordinate position of women in the social, political, and economic order. Despite this consensus, there have been few structural analyses of rape and inequality. Further, extant investigations suffer from a number of serious shortcomings such that, at present, there is not a sound basis for accepting, or rejecting, rape and inequality arguments. Correcting for many of the limitations of previous studies, this investigation extends our understanding of the role of gender socioeconomic inequality and other structural factors in the etiology of rape. The authors examine the relationship between rape rates and various measures of general, racial, and gender socioeconomic inequality for U.S. metropolitan areas. Their findings show that gender income inequality is a significant contributor to rape, but gender inequities in educational attainment and occupational status do not contribute significantly to this offense. The analysis also points to a number of other structural factors, including general income inequality, that are powerful predictors of rape.

Contemporary scholarship reflects a growing consensus that a major cause of rape lies in structural inequality in society, and particularly the subordinate position of women vis-à-vis men in the social, political, and economic orders. Despite this viewpoint, empirical analyses of rape and inequality have been very few in number. Moreover, existing studies suffer from a number of serious limitations such that they do not provide a basis for rejecting, or accepting, rape and inequality arguments. The purpose of this investigation is to further our understanding of the role of structural factors in rape by examining the relationship between rape rates and various measures of general, racial, and gender socioeconomic inequality for U.S. metropolitan areas for 1980 . 


\section{RECENT STRUCTURAL EXPLANATIONS OF RAPE}

Grounded in the feminist literature is the view that rape is a consequence of gender inequality (Brownmiller 1975; Griffin 1971; Sanday 1981; Schwendinger and Schwendinger 1983; Randall and Rose 1984; Herman 1988). The central argument is that rape is rooted in male domination of sociopolitical and economic activities (Williams and Holmes 1981). Thus, rape is expected to be more common where women hold little political or economic power, the sexes are highly segregated, and the occupational status of women is inferior. In such contexts, rape and other forms of sexual assault are viewed as functioning to maintain the subordination of women and preserve the system of male dominance. Through the humiliation and terror of rape, women are kept "in their place." "To eliminate rape ... disparities between the sexes in sociopolitical and economic power must be eliminated" (Ellis and Beattie 1983, p. 76).

Not all feminists are convinced that narrowing the gap between males and females in socioeconomic status will have the immediate effect of reducing rape. For example, Russell (1975) maintains that some men rape because they feel threatened by the prospect of women obtaining equality. Rape provides a way for such men to express their resentment and hostility. However, the concern about male "backlash" does not appear to negate the belief that the net effect of greater gender socioeconomic equality will be a decrease in the level of rape. Rather, Russell (1975) expresses concern about the reactions of "some men" only, while the benefits of parity in reducing violence against women are assumed to be far-reaching (Feldman-Summers and Palmer 1980; Williams and Holmes 1981; Schwendinger and Schwendinger 1983; Ellis 1989).

An additional line of argument contends that rape stems from general and racial inequality. Peter Blau and associates view high rates of violent crime in the United States, including rape, as a consequence of the plight of "have nots" in an affluent society (Blau and Blau 1982; Blau and Schwartz 1984; Blau and Golden 1986). In an affluent society that is also plagued by high levels of socioeconomic inequality in general, and racial inequality in particular, high rates of violent crime are to be expected. Indeed, the greater involvement of subordinate groups (the poor and Blacks) in crimes of violence is seen as largely a consequence of relative, and not absolute, deprivation. Similarly, Schwendinger and Schwendinger (1983) theorize that exploitative and oppressive social and economic conditions contribute to attitudes of contempt for and indifference to women (and others) that are 
expressed in rape and other forms of violence. For the Schwendingers, "the impoverishment of the working class and the widening gap between rich and poor ... will lead to worse conditions for the poor and a continued high incidence of sexual violence" (Schwendinger and Schwendinger 1983, p. 220).

\section{RECENT RESEARCH}

Although these theoretical arguments stress the importance of structural factors in rape, there is relatively little empirical literature on the role of system-level variables. Reflecting the theoretical perspectives noted above, studies follow two related, but somewhat distinct lines: a focus on the relationship between general and racial socioeconomic inequality and rape; or a focus on gender inequality and rape.

\section{General and Racial Inequality}

Conceptualizing socioeconomic inequality in general and racial terms, Blau and Blau (1982) conducted an analysis of rape rates (and other violent crimes) and levels of poverty, interracial (Black-White income differences, and the Black-White gap in Duncan SEI scores) and intraracial (the GINI Index of income inequality) socioeconomic inequality. Considering the 125 largest SMSAs for 1970, they found a chance only association between rape rates and each of their measures of absolute and relative deprivation. Two elaborations of the Blau and Blau (1982) analysis for the same SMSAs for 1970 (Blau and Schwartz 1984; Blau and Golden 1986) produced the same pattern of findings.

Smith and Bennett (1985) explored the possibility that the negative findings of the Blau et al. studies are a consequence of the use of police figures for rape that are unreliable due to variation in reporting by victims and the police. They examined a variation on the Blau and Blau (1982) model for a sample of SMSAs $(n=88)$ with average rape rates $(1979-1981)$ at least one standard deviation above or below the mean rate for all SMSAs. Smith and Bennett argue that it would be difficult to attribute the magnitude of difference in rape rates between the two extreme groups of SMSAs to reporting practices alone. However, their results do not challenge the Blaus' findings. Their measure of racial inequality (the Black-White income gap) showed virtually no association with rates. They do report a significant positive association between rape rates and percent poverty (i.e., absolute deprivation). Smith and Bennett conclude that this finding supports the 
Schwendinger and Schwendinger (1983) argument that poverty serves to breed an attitude of contempt for women.

In an extension of the Blau and Blau (1982) and Smith and Bennett (1985) analyses, Peterson and Bailey (1988) also found some support for rape and equality arguments. Examining average rape rates (1979-1981) for SMSAs $(n=243)$, and three dimensions of economic deprivation, they report support for the relative deprivation hypothesis for both general income inequality (the GINI Index) and racial income inequality (the Black-White gap in average earnings). However, a chance only association was observed between the level of poverty and rape rates.

\section{Rape and Gender Inequality}

Examining the male dominance argument, Ellis and Beattie (1983) considered the relationship between rape rates for 26 large metropolitan areas and male-female disparities in median earnings, years of education, levels of employment, participation in professional occupations, and the percent of judges, lawyers, and police who are female. Rape rates were computed on the basis of city-level FBI figures, victim survey data for each city, and FBI figures for the metropolitan areas containing the cities. Their partial correlation analysis did not yield a single instance of a significant positive association between the level of gender inequality and rape rates.

Baron and Straus $(1984,1987)$ conducted two follow-up investigations of the Ellis and Beattie study. In the first (1984) they examined the relationship between state-level FBI rape rates for 1979 and a composite Status of Women Index (SWX) reflecting four dimensions of male-female equality economic, educational, political, and legal. Contrary to expectations, their analysis produced a significant positive relationship between gender equality and rape rates. Baron and Straus conclude that this finding supports Russell's (1975) "backlash" argument that as the status of women increases, some men may retaliate in the form of rape to put women "back in their place."

In a second investigation, Baron and Straus (1987) considered average state-level rape rates (1980-1982) and a revised gender equality index (GEX) measuring male/female equality in three spheres of life: economic, political, and legal. In contrast to their earlier finding, they report a statistically significant $(t=-2.77, p<.01)$ negative relationship between rape rates and gender equality. Baron and Straus conclude that the pattern is consistent with the theory that gender inequality contributes to violence against women $\left(1987\right.$, p. 185). ${ }^{1}$ 


\section{ADEQUACY OF PREVIOUS INVESTIGATIONS}

Although the above studies provide limited evidence of a link between rape and socioeconomic inequality, due to a number of limitations of these analyses, it is premature to draw conclusions rejecting or accepting structural inequality arguments. Some of the problems apply broadly and others to specific studies. First, there are problems of model specification. The investigations by Blau and colleagues (Blau and Blau 1982; Blau and Golden 1986; Blau and Schwartz 1984), and Smith and Bennett (1985) ignore aspects of gender inequality as contributors to rape. In addition, this omission may have resulted in spurious findings for other factors of interest-poverty, general and racial socioeconomic inequality. By contrast, Ellis and Beattie (1983) failed to take into consideration dimensions of general and racial socioeconomic inequality. (In each of their analyses, Baron and Straus [1984, 1987, 1989] consider just one nongender dimension of economic deprivation.) As a consequence, it remains unknown how general and racial inequality may condition the relationship between rape and aspects of gender inequality.

Second, none of the above studies properly operationalize rape rates. (As defined by the FBI [1985, p. 13], forcible rape is "the carnal knowledge of a female forcibly and against her will.") In each study the numerator of the rape index is the number of female forcible rapes, but the denominator is the total rather than female population for the jurisdiction. This operationalization ignores the fact that the sex ratio is not uniform from jurisdiction to jurisdiction. If the sex ratio was a control variable in these analyses bias would be reduced, but none of the above studies includes such a measure.

Regarding problems of specific studies, due to the small number of jurisdictions examined $(n=26)$, and the relatively large number of sexual inequality (six) and control variables (eight) under consideration, degrees of freedom pose a very serious problem with the Ellis and Beattie (1983) study. As a result, the analysis was restricted to a series of first-order partial correlations, holding constant only one control variable at a time.

Baron and Straus $(1984,1987)$ deserve credit for considering rape and comprehensive measures of male-female differences in status. However, significant variation in the association between certain dimensions of sexual inequality and rape may have been obscured when combining multiple areas of inequality into single measures. Moreover, the Baron and Straus analyses produced conflicting results. Why should the level of gender equality spanning four important dimensions of social life (economic, educational, political, and legal) be associated with higher rape rates, and male-female equality 
in three dimensions of social life (economic, legal, and political) be associated with lower rates of rape? Baron and Straus fail even to speculate about the reason for their contrasting results.

The Baron and Straus studies also used a poorly suited unit of analysis. As Blalock (1982, p. 238) points out, "similarity is basic to the process of aggregation" (emphasis in original). In aggregating by geographic proximity, the objective is to form units that are as theoretically homogeneous as possible. However, states are very heterogeneous with respect to rape (and important sociodemographic characteristics). For example, for 1980 the average rape rate for the nation's SMSAs was 43.4 per 100,000 population. This compares to a rate of 20.6 for cities outside of SMSAs, and 15.5 for rural areas (FBI 1981, p. 41). This important intrastate variation in rape is masked when rates are computed at a state level.

\section{THE PRESENT INVESTIGATION}

In this investigation we avoid the above difficulties. Drawing on the theoretical works on general, racial, and gender inequality, we examine patterns of socioeconomic inequality and rates of forcible rape for U.S. metropolitan areas for 1980. Our primary interest is in rape and gender socioeconomic inequality. However, this question cannot be examined apart from considering other dimensions of inequality. As noted, a core assumption of some structural explanations is that rape, like other crimes of violence, is a consequence of general and racial inequality. Thus, studies of rape and gender inequality run the risk of spurious results if dimensions of general and racial inequality are ignored.

In addition to the inequality measures, we consider as control variables other structural factors linked with rape in the literature: the divorce rate, the percentage of the male population in the crime-prone years (16-34 years of age), percentage of the population that is Black, and the size of the metropolitan population, naturally log transformed because of skew.

\section{Metropolitan Rape Rates}

For all reporting SMSAs in $1980(n=263)$, figures on the number of female forcible rapes were drawn from the FBI's Uniform Crime Reports (1981), with rates being computed per 100,000 female population. The SMSAs reporting to the FBI represent 91\% (263/288) of all U.S. metropolitan areas in 1980 . Importantly, FBI figures underestimate the actual volume 
of rape. Not all rapes (only 52\%) are reported to the police (Bureau of Justice Statistics 1985). Thus the parameter estimates that appear later in the article underestimate the trade-off between inequality and rape rates. However, the underestimation problem does not preclude this type of analysis. FBI figures provide a reasonable indicator of the relative incidence of rape across jurisdictions (Hindelang 1974; Gove, Hughes and Geerken 1985).

\section{Socioeconomic Variables}

Required data for $\mathbf{1 9 8 0}$ for the socioeconomic and demographic control variables were taken from U.S. Bureau of the Census reports. The percentages of families below the poverty line is used as a measure of absolute economic deprivation. ${ }^{2}$ The GINI Index is used to assess general income inequality. The Black and White median family income gap provides a measure of racial economic inequality. Gender socioeconomic inequality is measured as the differential between males and females in income, education, occupations, and poverty. For education, inequality is assessed by the percentage of adult males versus females who have completed (a) 4 years of high school, (b) 4 years of college, and (c) 5 or more years of college. Gender economic inequality is measured by contrasting the median income of males and females for (a) all persons with incomes, (b) persons who have completed 4 years of high school, and (c) those who have completed 4 or more years of college. Occupational inequality is measured by the percentage of employed persons (16 years old and over) in managerial and professional occupations (and in different types of professional occupations) who are female. The male-female poverty gap for individuals provides a fourth measure of gender economic inequality.

We do not pose the above measures as a complete inventory of how gender socioeconomic inequality can be operationalized. Rather, we are guided by how sexual inequality is viewed conventionally in the social stratification literature, and by established social indicators of gender socioeconomic inequality (U.S. Commission on Civil Rights 1978).

\section{Time-Frame and Units}

We use SMSAs as units of analysis for two reasons. First, they are common units in previous structural analyses of rape. Second, detailed genderspecific income, education, and occupational data are available from published census reports for SMSAs but not for smaller units such as cities or 
towns. We consider 1980 because it is the most recent year where published figures are available for the required socioeconomic and demographic data.

\section{Missing Data}

For the 263 SMSAs where 1980 rape data are available, census figures are available for the control variables, the measures of general and racial socioeconomic inequality, and for male-female inequality in (a) median income, (b) percentage of persons employed in professional and managerial occupations, and (c) percentage of persons with 4 years of high school, with 4 years of college, and with 5 or more years of college. Unfortunately, figures necessary to compute male-female differentials in (a) the percentage of individuals with incomes below the poverty line, and (b) the median earnings of persons by level of education are not available for all SMSAs. Rather, required data are only available from census publications for jurisdictions with at least 250,000 population. Accordingly, this part of the analysis is restricted to a subsample of 147 large metropolitan areas.

\section{Multicollinearity}

Multicollinearity does not pose a problem for the inequality variables. For each model considered a series of auxiliary analyses were conducted in which each dimension of inequality was regressed against the other predictors. In no case were the inequality measures tied so closely to one another or the demographic variables as to distort the regression results. ${ }^{3}$

\section{FINDINGS}

Table 1 reports the regression results where male-female inequality in median income, percentage of high school graduates, and percentage of persons in professional and managerial occupations that are female are examined individually, and when the three dimensions of gender inequality are combined in a single analysis. As found in some previous studies, there are positive and significant relationships between rape rates and the percentage of male population 16-34 years of age, the size of the Black population, and the divorce rate.

Consistent with predictions, the GINI Index is a significant predictor of rape rates throughout the analysis, but the poverty variable is not. This pattern is consistent with the Blaus's (1982) argument that relative, but not absolute, 
RAPE AND DIMENSIONS

TABLE 1: Results for Rape Rates Regressed Against Three Dimensions of Gender Inequality in Socioeconomic Status

\begin{tabular}{|c|c|c|c|c|c|c|c|c|}
\hline Predictor Variable & $B$ & beta & $B$ & beta & $B$ & beta & $B$ & beta \\
\hline Log population & 2.187 & $.076^{\star}$ & 3.360 & $.091^{*}$ & 3.905 & $.106^{\star}$ & 3.269 & $.088^{*}$ \\
\hline $\begin{array}{l}\text { Percentage of Black population } \\
\text { Percentage of males, }\end{array}$ & 1.078 & $.286^{\star \star \star}$ & 1.066 & $.283^{\star \star \star}$ & 1.013 & $.268^{\star \star \star}$ & 0.950 & $.252^{\star \star \star}$ \\
\hline $16-34$ years old & 1.439 & $.201^{\star \star \star}$ & 1.156 & $.126^{\star \star \star}$ & 1.171 & $.164^{\star \star \star}$ & 1.411 & $.197^{\star \star \star}$ \\
\hline Divorce rate & 13.780 & $.531^{\star \star \star}$ & 13.898 & $.536^{\star \star *}$ & $13.843^{\star \star}$ & $.533^{\star \star \star}$ & 13.626 & $.525^{\star \star \star}$ \\
\hline Percentage of family poverty & -0.181 & -.017 & -0.198 & -.019 & -0.335 & -.032 & -0.593 & -.057 \\
\hline General income inequality & 394.3 & $.272^{\star \star \star}$ & 287.4 & $.199 * \star$ & 296.5 & $.205^{\star \star \star}$ & 426.1 & $.294^{\star \star \star}$ \\
\hline $\begin{array}{l}\text { Black-White income inequality } \\
\text { Gender inequality in median }\end{array}$ & 0.910 & .072 & 1.144 & $.091^{\star}$ & 1.142 & $.093^{\star}$ & 0.969 & .077 \\
\hline $\begin{array}{l}\text { income } \\
\text { Gender inequality in percentage }\end{array}$ & 2.296 & $.114^{\star}$ & - & - & - & - & 2.621 & $.130^{\star}$ \\
\hline $\begin{array}{l}\text { of high school graduates } \\
\text { Gender inequality in percentage }\end{array}$ & - & - & .236 & .015 & - & - & .382 & .025 \\
\hline of professional occupations & - & - & - & - & .583 & .046 & .889 & .070 \\
\hline $\begin{array}{l}\text { Constant } \\
R^{2} \text { /adjusted } R^{2}\end{array}$ & $\begin{array}{l}-276.2^{\star \star \star} \\
.622 / .610^{\star \star \star}\end{array}$ & & $\begin{array}{l}-221.4^{\star \star \star} \\
.616 / .604^{\star \star \star}\end{array}$ & & $\begin{array}{l}-253.6^{\star \star \star} \\
.617 / .605^{\star \star \star}\end{array}$ & & $\begin{array}{l}-326.1^{\star \star \star} \\
.625 / .610^{\star \star \star}\end{array}$ & \\
\hline
\end{tabular}

${ }^{\star} p<.05 ;{ }^{\star \star} p<.01 ; * \star{ }^{*} p<.001$. 
economic deprivation is a major contributor to violence. Results for the White-Black income-inequality factor are partially consistent with the Blaus' argument. The higher the White-Black income gap, the higher the rape rate, and significantly so when gender inequality is defined in educational and occupational terms. When gender inequality is operationalized as the malefemale differential in income, the White-Black income-gap variable falls just short of achieving statistical significance $(p .<.063$ to .074$)$ by conventional standards. ${ }^{4}$

Table 1 provides only partial support for the rape and sexual inequality argument. Rape rates and the male-female income gap are associated positively and significantly $(\mathrm{b}=2.296, p<.05)$. For every $\$ 1,000$ unit increase (male advantage) in the male-female earnings gap, the rape rate increases by a factor of 2.3 per 100,000 female population. This relationship is not reduced $(b=2.621, p<.05)$ when the other dimensions of sexual inequality are incorporated into the regression. In contrast, Table 1 shows a chance only association between rates and the male-female gap in the percentage of high school graduates, and the percentage of females in professional and managerial occupations.

To better understand the nature of the relationship between rape and economic inequality, we differentiate the male-female income gap by levels of educational attainment, and examine the percentage of male and female individuals with incomes below the poverty line. The question of interest was whether the predicted findings for rape and sexual income inequality (Table 1) are a consequence of gender inequality for certain subpopulations. This analysis did not add greater precision to our understanding of rape and gender income inequality. There is wide variation across metropolitan areas in the income of males and females with a high school education $(\bar{x}=$ $\$ 7,264, S D=\$ 1,949$, range $=\$ 10,913)$, with 4 or more years of college $(\bar{x}=$ $\$ 10,299, S D=\$ 1,726$, range $=\$ 10,506)$, and in the male-female differential in poverty status $(\bar{x}=8.5 \%, S D=4.8 \%$, range $=17.9 \%)$. However, this variation is not related significantly to rape rates. (Tabular results are available on request.)

On the assumption that the contrary findings for the male-female gap in achieving a high school education might be due to the rather restricted range of this variable $(\bar{x}=1.81 \%, S D=2.35 \%)$, we examined the impact of malefemale differences in the levels of college education. There is a somewhat greater level of gender inequality (male advantage) in completing 4 years of college $(\bar{x}=2.21 \%, S D=1.28 \%)$, and 5 or more years of college $(\bar{x}=5.08 \%$, $S D=2.34 \%)$. This analysis provided no indication that sexual inequality in 
higher education is a significant contributor to rape. (Tabular results are available on request.)

An additional subsidiary analysis was conducted to assess whether the negative findings reported in Table 1 for rape and the male-female gap of participation in all types of professional and managerial occupations combined may be due to the broad range of occupations and professions included in this category. Therefore, we examined more homogeneous professional and managerial occupational groupings - some traditional male occupations (e.g., executives, engineers, scientists, physicians) and some not (librarians, school teachers). The results of this analysis are presented in Table 2.

The findings are mixed for the occupational gender inequality measures. Contrary to expectations, the greater the percentage of executives, administrators, and managers that are females $(\bar{x}=29.9 \%)$, the higher the rape rate $(\mathrm{b}=1.472, p<.05)$. This finding is consistent with the "backlash" argument that higher levels of female participation in more prestigious and better paying positions may result in higher levels of male resentment, with rape providing a means of striking back (Russell 1975).

The significant negative relationship $(b=-.953, p<.01)$ between rape and the percentage of elementary and secondary school teachers who are female also may be viewed as evidence of backlash. The more that women remain in traditional "female" occupations, the greater their "reward" freedom from rape. However, for three other occupational groupings (which have minority female participation), the gender inequality coefficients are negative: public officials and public administrators $(\bar{x}=30.3 \%, b=-.171)$; engineers and natural scientists $(\overline{\mathrm{x}}=9.3 \%, \mathrm{~b}=-.064)$; and health diagnostic professionals $(\overline{\mathrm{x}}=9.6 \%, \mathrm{~b}=-.832)$. Moreover, the negative coefficient for rape and level of female participation in health diagnostic professions (physicians, dentists, chiropractors, podiatrists, veterinarians) is statistically significant. These latter findings raise questions regarding the merits of the backlash argument. If rape results, at least in part, from male backlash, then how does one account for the lack of an apparent backlash for these additional occupational categories?

\section{SUMMARYAND CONCLUSION}

This analysis points to one aspect of gender inequality as a significant contributor to rape. The greater the income gap between males and females, the higher the rape rate. On average, every $\$ 1,000$ unit advantage in the earnings of males over females is associated with a 2.3 person increase in the 


\section{RAPE AND DIMENSIONS}

TABLE 2: Results for Rape Rates Regressed Against Five Dimensions of Gender Inequality in Occupational Status

\begin{tabular}{|c|c|c|c|c|c|c|c|c|c|c|}
\hline Predictor Variable & $\boldsymbol{B}$ & beta & $B$ & beta & $B$ & beta & $B$ & beta & $B$ & beta \\
\hline $\begin{array}{l}\text { Log population } \\
\text { Percentage of Black }\end{array}$ & 3.414 & $.093^{\star}$ & 3.411 & $.092^{\star}$ & 3.476 & $.094^{\star}$ & 4.475 & $.121^{\star \star}$ & 2.272 & .061 \\
\hline $\begin{array}{l}\text { population } \\
\text { Percentage of males, }\end{array}$ & 0.975 & $.258^{\star \star \star}$ & 1.084 & $.287^{\star \star \star}$ & 1.084 & $.287 \star \star \star$ & 1.176 & $.312^{\star \star \star}$ & 1.468 & $.389^{\star \star \star}$ \\
\hline $16-34$ years old & 0.923 & $.129 \star \star$ & 1.174 & $.164^{\star \star \star}$ & 1.195 & $.167^{\star \star \star}$ & 1.225 & $.171^{\star \star \star}$ & 1.237 & $.173^{\star \star \star}$ \\
\hline Divorce rate & 12.426 & $.479^{\star \star \star}$ & 14.026 & $.540^{\star \star \star}$ & 13.919 & $.536^{\star \star \star}$ & 13.828 & $.533^{\star \star \star}$ & 14.262 & $.550 * \star \star$ \\
\hline Percentage of family poverty & 0.004 & .000 & -0.123 & -.011 & -0.166 & -.016 & -0.563 & -.053 & -0.308 & -.029 \\
\hline General income inequality & 225.9 & $.156^{\star}$ & 227.0 & $.191^{\star \star}$ & 290.0 & $.200^{\star \star}$ & 325.0 & $.224^{\star \star \star *}$ & 375.8 & $.247^{\star \star \star}$ \\
\hline $\begin{array}{l}\text { Black-White income inequality } \\
\text { Percentage of executives, } \\
\text { administrators, and }\end{array}$ & 1.283 & $.102^{\star}$ & 1.147 & $.091^{\star}$ & 1.126 & $.090^{\star}$ & 1.142 & $.091^{\star}$ & 1.215 & $.097^{\star}$ \\
\hline $\begin{array}{l}\text { managers that are female } \\
\text { Percentage of public officials } \\
\text { and administrators that }\end{array}$ & 1.472 & $.126^{\star}$ & - & - & - & - & - & - & - & - \\
\hline $\begin{array}{l}\text { are female } \\
\text { Percentage of engineers and } \\
\text { natural scientists that are }\end{array}$ & - & - & -.171 & -.036 & - & - & - & - & - & - \\
\hline $\begin{array}{l}\text { female } \\
\text { Percentage in health diagnostic }\end{array}$ & - & - & - & - & -.064 & -.006 & - & - & - & - \\
\hline $\begin{array}{l}\text { occupations that are femals } \\
\text { Percentage of elementary and } \\
\text { secondary teachers that are }\end{array}$ & - & - & - & - & - & - & -.832 & $-.093^{\star}$ & - & - \\
\hline female & - & - & - & - & - & 一 & - & - & -.953 & $-.168^{\star \star}$ \\
\hline $\begin{array}{l}\text { Constant } \\
R^{2} \text { /adjusted } R^{2}\end{array}$ & $\begin{array}{l}-227.8^{\star \star \star} \\
.623 / .611 \star \star \star\end{array}$ & & $\begin{array}{l}-215.2^{\star \star \star} \\
.617 / .605^{\star \star \star}\end{array}$ & & $\begin{array}{l}-224.7 \\
.616 / .603\end{array}$ & . & $\begin{array}{l}-240.3^{\star \star \star} \\
.622 / .610^{\star \star \star}\end{array}$ & & $\begin{array}{l}-172.2^{\star \star \star} \\
.628 / .616^{\star \star \star}\end{array}$ & \\
\hline
\end{tabular}

${ }^{\star} \mathrm{p}<.05 ;{ }^{\star \star} \mathrm{p}<.01 ; \star \star \star \mathrm{p}<.001$ 
rape rate. Other things being equal, if the income gap between males and females was reduced to zero, the rape rate would be reduced by 16.34 persons per 100,000 female population $(2.3 \times 7.1=16.3)$. However, we find no evidence that rape patterns are tied to gender inequality in educational attainment. And, no clear and consistent patterns emerge indicating that the level of female participation in professional and managerial occupations is associated with the rape problem.

The fact that our findings show that only gender inequality in income consistently is linked to rape does not come as a total surprise. There is evidence to suggest that many rapes are not as much sex offenses as they are crimes of power, serving as a means for insecure men to express control and mastery over women (Groth and Birnbaum 1979). Further, in American society, power differentials among citizens are largely a consequence of income (and wealth) rather than educational attainment and occupational position (Blumberg 1978, 1984). This being the case, one might anticipate that the dimension of gender inequality that is most important in conferring power (income) would also be the aspect of gender inequality that is associated most closely with rape.

Although our primary concern has been with rape and gender socioeconomic inequality, other structural variables were considered. Some of these variables proved to be very powerful predictors of rape. For example, rape rates are associated with the general level of economic inequality (the GINI Index) but not with levels of poverty. This pattern supports the argument that criminal violence-including rape-is more a consequence of relative than absolute economic deprivation (Blau and Blau 1982; Blau and Schwartz 1984; Blau and Golden 1986).

We also found a significant positive association between rape and racial income inequality throughout much of the analysis. Thus it would appear that the rape problem is at least in part a cost of racial economic inequality in this society (Blau and Blau 1982).

In sum, there is evidence that one dimension of gender inequality - the income gap - is a significant contributor to rape. However, our analysis by no means settles the issue of rape and the structural position of women vis-à-vis men. First, we have examined the rape and gender inequality question using 1980 data because this is the latest year for which required national figures are available to construct theoretically meaningful indicators of gender inequality. Importantly, these data are now more than a decade old. Since 1980 the proportions of women in higher education, the labor force, and professional and managerial occupations have increased. In addition, the male-female income gap has narrowed. ${ }^{5}$ However, not until the 1990 census 
data become available will it be possible to extend our analysis to this more recent period.

Second, we have had to rely on rather limited FBI rape data. These data do not differentiate (a) actual versus attempted rapes, nor do they distinguish rapes by (b) victim and offender characteristics, (c) the nature of the victimoffender relationship, or (d) the setting and characteristics of the offense, including degree and type of injury to victims, the use of weapons, the number of parties involved, and the like. Fortunately, the FBI is now in the process of implementing a reporting system where crime victim, offender, relationship, circumstance, and situational data are collected on an "incident" basis for 22 offenses, including rape. As of January 1991, nine states had submitted incident-based test data to the FBI, and 16 others had plans to do so by the end of 1991 . The remaining states are expected to join the incidentbased reporting system within the next few years (J. Harper Wilson, Director, Uniform Crime Reporting Program, personal communication, January 17, 1991).

With the release of 1990 census data and increasing participation in the FBI incident-based crime reporting program, future investigators will be able to extend significantly our understanding of rape and inequality. For example, these data will allow researchers to examine patterns of inter- and intraracial rape under varying conditions of general and racial inequality. In addition, they will permit us to explore the association between various dimensions of gender inequality and the incidence of rape for participants in different types of settings and relationships (e.g., strangers, acquaintances, friends, intimates, and the like). In short, the next few years hold the promise of significantly extending our understanding of the etiology of the rape, including its linkage to various dimensions of inequality.

\section{NOTES}

1. The 1987 analysis also appears in a 1989 book by Baron and Straus, Four Theories of Rape in American Society: A State Level Analysis. Because the findings and conclusions of the 1987 and 1989 publications are the same, the latter work does not require discussion here.

2. A reviewer of an earlier version of this article suggested three alternatives to the use of the conventional percent family poverty variable: (a) the infant mortality rate, (b) percentage of persons with less than 5 years of formal education, and (c) percentage of families with very low incomes-less than $\$ 5,000$. When each of these variables was substituted in the analysis for the poverty measure, none proved to be a significant predictor of rape. Nor did their inclusion alter the results for the gender inequality variables.

3. For the analyses to follow, the resulting $R^{2}$ values from the auxiliary regressions are: divorce rate, percentage of males 16-34 years ( .50), GINI Index ( .70), poverty ( . .75), gender 


\section{RAPE AND DIMENSIONS}

income inequality (.302 to .550$)$, gender educational inequality (.337 to .543$)$, female participation in professional occupations (.037 to .551$)$, and gender inequality in poverty status (.334).

4. Of note, there is no evidence of a significant nonlinear association between percentage poverty and Black-White income inequality and rape rates.

5. To illustrate, between 1980 and 1988 the proportion of college students who are women increased by approximately $3 \%$ from $51.4 \%$ to $53.7 \%$; women in the civilian labor force increased from $52 \%$ to $57 \%$; professionals and persons in managerial specialty occupations who are female increased from $42 \%$ to $45 \%$; and the gender gap in median income narrowed from $64.7 \%$ to $42.9 \%$ (U.S. Department of Commerce 1982a, 1982b, 1990, 1991).

\section{REFERENCES}

Baron, Larry and Murray A. Straus. 1984. "Sexual Stratification, Pornography, and Rape in the United States." Pp. 185-209 in Pornography and Sexual Aggression, edited by N. M. Malamuth and E. Donnerstein. New York: Academic Press.

- 1987. "Four Theories of Rape: A Macrosociological Analysis." Social Problems 34:467-89.

1989. Four Theories of Rape in American Society: A State Level Analysis. New Haven, CT: Yale University Press.

Blalock, Hubert M. 1982. Conceptualization and Measurement in the Social Sciences. Beverly Hills, CA: Sage.

Blau, Judith R. and Peter M. Blau. 1982. "The Cost of Inequality: Metropolitan Structure and Violent Crime.” American Sociological Review 47:114-29.

Blau, Peter M. and Reid M. Golden. 1986. "Metropolitan Structure and Criminal Violence." The Sociological Quarterly 27:15-26.

Blau, Peter M. and Joseph E. Schwartz. 1984. Crossing Social Circles: Testing a Macrostructural Theory of Intergroup Relations. Orlando, FL: Academic Press.

Blumberg, Rae Lesser. 1978. Stratification: Socioeconomic and Sexual Stratification. Dubuque, IA: W. C. Brown.

- 1984. "A General Theory of Gender Stratification.” Pp. 23-101 in Sociological Theory, edited by Randall Collins. San Francisco: Jossey-Bass.

Brownmiller, Susan. 1975. Against Our Will: Men, Women and Rape. New York: Simon \& Schuster.

Bureau of Justice Statistics. 1985. The Crime of Rape. Washington, DC: U.S. Government Printing Office.

Ellis, Lee. 1989. Theories of Rape: Inquiries Into the Causes of Sexual Aggression. New York: Hemisphere.

Ellis, Lee and Charles Beattie. 1983. "The Feminist Explanation of Rape: An Empirical Test." Journal of Sex Research 19:74-93.

Federal Bureau of Investigation. 1981. Crime in the United States: Uniform Crime Reports, 1980. Washington, DC: U.S. Government Printing Office.

1985. Crime in the United States: Uniform Crime Reports, 1984. Washington, DC: U.S. Government Printing Office.

Feldman-Summers, Shirley and Gayle Palmer. 1980. "Rape: A View From Judges, Prosecutors, and Police Officers." Criminal Justice and Behavior 7:19-40. 
Gove, Walter R., Michael Hughes, and Michael Geerken. 1985. "Are Uniform Crime Reports a Valid Indicator of the Index Crimes?: An Affirmative Answer with Minor Qualifications." Criminology 23:451-91.

Griffin, Susan. 1971. "Rape, the All-American Crime." Ramparts 10:26-35.

Groth, Nicholas A. and H. Jean Birnbaum. 1979. Men Who Rape: The Psychology of the Offender. New York: Plenum.

Herman, Judith Lewis. 1988. "Considering Sex Offenders: A Model of Addiction.” Signs 13:695-724.

Hindelang, Michael J. 1974. "The Uniform Crime Reports Revisited." Journal of Criminal Justice 2:1-17.

Peterson, Ruth D. and William C. Bailey. 1988. "Forcible Rape, Poverty, and Economic Inequality in U.S. Metropolitan Communities." Journal of Quantitative Criminology 4:99-119.

Randall, Susan and Vicki McNickle Rose. 1984. "Forcible Rape." Pp. 47-72 in Major Forms of Crime, edited by Robert F. Meier. Beverly Hills, CA: Sage.

Russell, Diana E. H. 1975. The Politics of Rape, the Victim's Perspective. New York: Stein \& Day. Sanday, Peggy. 1981. Female Power and Male Dominance: On the Origins of Sexual Inequality. London: Cambridge University Press.

Schwendinger, Julia H. and Herman Schwendinger. 1983. Rape and Inequality. Beverly Hills, CA: Sage.

Smith, M. Dwayne and Nathan Bennett. 1985. "Poverty, Inequality, and Theories of Forcible Rape." Crime \& Delinquency 31:295-305.

United States Commission on Civil Rights. 1978. Social Indicators of Equality for Minorities and Women. Washington, DC: U.S. Government Printing Office.

United States Department of Commerce, Bureau of the Census. 1982a. 1980 Census of Population: Social and Economic Characteristics. Washington, DC: U.S. Government Printing Office.

-1982b. Statistical Abstracts of the United States: 1981. Washington, DC: U.S. Government Printing Office.

1990. Statistical Abstracts of the United States: 1989. Washington, DC: U.S. Government Printing Office.

- 1991. Statistical Abstracts of the United States: 1990. Washington, DC: U.S. Government Printing Office.

Williams, Joyce and Karen Holmes. 1981. The Second Assault: Rape and Public Attitudes. Westport, CT: Greenwood.

Wilson, Nanci Koser. 1985. "Venerable Bedfellows: Women's Liberation and Women's Victimization." Victimology 10:206-20. 